\title{
EFFECT OF BREADFRUIT LEAF EXTRACT ON THE VIABILITY OF STREPTOCOCCUS MUTANS BIOFILM IN VITRO
}

\author{
SEPTI WARDA ZULFIKAR, SRI UTAMI, RATNA FARIDA*
}

Department of Oral Biology, Faculty of Dentistry, Universitas Indonesia, Jalan Salemba Raya No.4, Jakarta Pusat, 10430, Indonesia. Email: friedakuayu@yahoo.co.id

Received 28 September 2018, Revised and Accepted 22 February 2019

\section{ABSTRACT}

Objective: Breadfruit leaf has potent antibacterial properties that could be used to reduce biofilms in the oral cavity. The purpose of this study was to analyze the antibacterial effect of the breadfruit leaf extract on the growth of Streptococcus mutans in vitro.

Methods: S. mutans ATCC 25175 was cultured in a 96-well plate and incubated at $37^{\circ} \mathrm{C}$ for $20 \mathrm{~h}$ (accumulation phase) and $24 \mathrm{~h}$ (maturation phase). The breadfruit leaf extract was added at the following concentrations: $5 \%, 10 \%, 15 \%, 20 \%, 40 \%, 80 \%$, and $100 \%$. The viability of $S$. mutans was tested with the MTT assay at a wavelength of $490 \mathrm{~nm}$. The results were analyzed by one-way analysis of variance.

Results: In the accumulation phase, a significant decrease was found in $S$. mutans viability at different concentrations of the breadfruit leaf extract, but in the maturation phase, a significant decrease was found in the $S$. mutans viability at the $5 \%$ concentration. The other groups decreased significantly compared with the control group (*p<0.05). The viability of $S$. mutans after adding the breadfruit leaf extract at all concentrations was lower in the accumulation phase than that in the maturation phase.

Conclusion: In the accumulation phase, breadfruit leaf extract at concentrations of 5\%, 10\%, 20\%, 40\%, 80\%, and 100\% can reduce S. mutans biofilm viability.

Keywords: Extract of breadfruit leaf, Streptococcus mutans, Viability, MTT assay.

(C) 2019 The Authors. Published by Innovare Academic Sciences Pvt Ltd. This is an open access article under the CC BY license (http://creativecommons. org/licenses/by/4. 0/) DOI: http://dx.doi.org/10.22159/ijap.2019.v11s1.AR201

\section{INTRODUCTION}

Medicinal plants are natural materials derived from plants that are traditionally used by communities but have not been scientifically tested. They significantly improve community health when they are used in the correct doses, implementation, and time. A medicinal plant with considerable potential for human health is Artocarpus altilis, also known as breadfruit [2].

Breadfruit is distributed throughout the tropics and its tree is sturdy, tall, and leafy [2]. Its fruit is used as food and its leaves have been used to treat various diseases such as kidney disease, diabetes mellitus, high cholesterol, and canker sores [3].

Streptococcus mutans is a Gram-positive, non-motile, and an anaerobic facultative bacterium that plays an important role in the formation of biofilms in the oral cavity [4]. The first phase of biofilm formation is known as the $0-4 \mathrm{~h}$ adhesion phase, during which $S$. mutans is able to attract other microorganisms. The maturation phase happens after $20 \mathrm{~h}$, during which $S$. mutans releases a glycosyltransferase enzyme that causes the glucose polymerization of sucrose by releasing fructose. Glucose is then converted to lactic acid. When a large amount of lactic acid is created, they decrease the $\mathrm{pH}$ to a critical value of 5.5 , causing dental demineralization [5-7].

In dentistry, antibacterial compounds are used to decrease plaque accumulation. Abdassah et al. stated that the phytochemical of the breadfruit leaf extract contains active antibacterial compounds, such as flavonoid, polyphenol, quinone, steroid, saponin, monoterpene, and sesquiterpene, making our study important [8]. Breadfruit leaf was extracted by maceration using $70 \%$ ethanol as a solvent [8]. The antibacterial activity of breadfruit leaf depends on the concentration and contact time of the antibacterial compound [9]. The purpose of this study was to analyze the antibacterial effect of the breadfruit leaf extract on the viability of $S$. mutans biofilm at different concentrations and contact times.

\section{METHODS}

S. mutans ATCC 25175 was obtained from the Oral Biology Laboratory, Faculty of Dentistry, Universitas Indonesia, Indonesia, where the study was conducted. The sample of the breadfruit leaf extract was obtained from the Medicinal and Aromatic Medicine Research Halls (BALITRO), Bogor, Indonesia. Artificial saliva was obtained from the Biochemistry Laboratory of the Faculty of Medicine, Universitas Indonesia, Indonesia. In this study, the positive control used was $0.2 \%$ chlorhexidine and BHI broth was added with a ratio of 1:1. The viability of $S$. mutans was tested with the MTT assay at a wavelength of $490 \mathrm{~nm}$.

\section{Preparation of $S$. mutans main solution}

The main solution of $S$. mutans was prepared by taking some bacterial colonies grown on $\mathrm{BHI}$ agar and placing in a reaction tube containing $10 \mathrm{~mL}$ of $\mathrm{BHI}$ broth. The reaction tube was placed in an anaerobic jar filled with $\mathrm{NO}_{2}$ and $5 \% \mathrm{CO}_{2}$ gas and incubated for $24 \mathrm{~h}$ at $37^{\circ} \mathrm{C}$.

Making of various concentrations of the breadfruit leaf extract The breadfruit leaf extract was filtered using a 10-mL syringe and a 0.2-mm diameter Minisart. This was necessary to filter the portion of the breadfruit leaf extract that may interfere in reading the OD value. The breadfruit leaf extract was prepared at concentrations of $5 \%$, $10 \%, 20 \%, 40 \%, 80 \%$, and $100 \%$. The artificial saliva was composed of $12 \mathrm{mM} \mathrm{NaCl}, 3.4 \mathrm{mM} \mathrm{KSCN}, 17.8 \mathrm{mM} \mathrm{NaHCO}_{3}, 1.5 \mathrm{mM} \mathrm{Na}_{2} \mathrm{HPO}_{4}, 1.5 \mathrm{mM}$ $\mathrm{KH}_{2} \mathrm{PO}_{4}$, and $2.2 \mathrm{mM}$ urea in an aqueous solvent.

Biofilm formation was performed first in 96-well plates by adding $100 \mu \mathrm{L}$ of artificial saliva in each well. The plates were then incubated 
for $90 \mathrm{~min}$ at $37^{\circ} \mathrm{C}$. Saliva not attached to the well base was removed and wells were washed with $100 \mu \mathrm{L}$ PBS. Then, $100 \mu \mathrm{L}$ of diluted and standardized bacteria with a concentration of $106 \mathrm{CFU} / \mathrm{mL}=0.061$ was added to the 96-well plate, and the plate was placed in $95 \% \mathrm{NO}_{2}$ and $5 \% \mathrm{CO}_{2}$. The plates were incubated for $20 \mathrm{~h}$ and a further $24 \mathrm{~h}$ at $37^{\circ} \mathrm{C}$. Bacteria that were attached to the 96 -well plate were rinsed with $100 \mu \mathrm{L}$ phosphate-buffered saline (PBS).

\section{Exposure of breadfruit leaf extract and MTT test}

In each well plate that was washed with PBS, $100 \mu$ l of the breadfruit leaf extract was added at various concentrations (5\%, 10\%, 20\%, 40\%, $80 \%$, and $100 \%$ ) to each well plate. For the positive control, $100 \mu \mathrm{L}$ of $0.1 \%$ chlorhexidine $(0.2 \%$ chlorhexidine mixed with BHI $1: 1)$ was added to each well. For the negative control, BHI broth was added to each well. The well plate was inserted into an anaerobic jar with $90 \%$ $\mathrm{NO}_{2}$ and $5 \% \mathrm{CO}_{2}$ and was incubated for $2 \mathrm{~h}$ at $37^{\circ} \mathrm{C}$. The MTT test was performed by adding $50 \mu \mathrm{L}$ into 96 -well plate and incubated for $3 \mathrm{~h}$ at $37^{\circ} \mathrm{C}$. Then, $100 \mu \mathrm{L}$ of acidified isopropanol was added into each well and the plate was observed on a microplate reader at a wavelength of $490 \mathrm{~nm}$. The percentage of biofilm viability was examined using the following formula:

$$
\text { Viability }=\frac{\text { OD value of treated group }}{\text { OD value of control group }} \times 100 \%
$$

\section{Data analysis}

The percentage of each $S$. mutans treated group viability was tested using one-way analysis of variance.

\section{RESULTS}

The normality test, Kolmogorov-Smirnov, showed that the data had a normal distribution $(\mathrm{p}>0.05)$

In the accumulation phase $(20 \mathrm{~h})$, the viability of $S$. mutans control group was $100 \%$ (OD, $1.541 \pm 0.035$ ) (Fig. 1). $0.1 \%$ chlorhexidine positive control group had a viability of $9 \%$ (OD, $0.137 \pm 0.010$ ) (Fig. 1). In the breadfruit leaf extract exposure group, at $5 \%$ concentration, the viability was $82 \%$ (OD, $1.265 \pm 0.023$ ). In $10 \%$ concentration group, the viability was $79 \%$ (OD, $1.217 \pm 0.038$ ); in $20 \%$ concentration group, the viability was $56 \%$ (OD, $0.867 \pm 0.037$ ); in $40 \%$ concentration group, the viability was $50 \%(\mathrm{OD}, 0.44 \pm 0.016)$; in $80 \%$ concentration group, the viability was $36 \%$ (OD, $0.77 \pm 0.038$ ); and in $100 \%$ concentration group, viability was $29 \%$ (OD, 0.561 \pm 0.031 ) (Fig. 1). $S$. mutans viability declined with increasing concentration of the breadfruit leaf extract in the accumulation phase (Fig. 1). All the treated groups significantly differed from the control group $\left({ }^{*} \mathrm{p}<0.05\right)$.

In the maturation phase ( $24 \mathrm{~h}$ ), the viability of $S$. mutans control group was $100 \%(\mathrm{OD}, 0.953 \pm 0.061$ ) in the negative control group and $18 \%$
(OD, $0.173 \pm 0.010$ ) in $0.1 \%$ chlorhexidine positive control group (Fig. 2). In the breadfruit leaf extract exposure group, at $5 \%$ concentration, $S$. mutans viability was higher than the control group of $117 \%$ (OD $1,119 \pm 0.054)$. S. mutans viability was $92 \%$ (OD, $0.877 \pm 0.059$ ) at a concentration of $10 \%, 79 \%(O D, 0.755 \pm 0.039)$ at a concentration of $20 \%, 68 \%$ (OD, $0.647 \pm 0.032$ ) at a concentration of $40 \%, 65 \%$ (OD, $0.621 \pm 0.027$ ) at a concentration of $80 \%$, and $59 \%$ (OD, $0.566 \pm 0.047$ ) at a concentration of $100 \%$ (Fig. 2). S. mutans viability declined with increasing concentration of the breadfruit leaf extract in the maturation phase. All treated groups significantly differed from the negative control group $\left({ }^{*} \mathrm{p}<0.05\right)$.

S. mutans biofilm viability in $0.1 \%$ chlorhexidine group in the accumulation phase was lower than that in the maturation phase (Fig. 3). The same results were observed for the groups exposed to different concentrations of the breadfruit leaf extract (Fig. 3). There was a significant decrease in $S$. mutans viability in the accumulation phase compared with that in the maturation phase.

\section{DISCUSSION}

Breadfruit leaf extract at concentrations of 5\%, 10\%, 20\%, 40\%, 80\%, and $100 \%$ decreased $S$. mutans biofilm viability during the accumulation phase $(20$ h) (Fig. 1). During the maturation phase, breadfruit leaf extract at a concentration of $5 \%$ significantly increased the S. mutans biofilm viability (Fig. 2)

Based on research conducted by Purnamasari et al., antibacterial effects are stronger with higher concentrations of cocoa seed extract due to the greater active compound content of the extract [10]. Breadfruit leaf contains active compounds such as flavonoid, polyphenol, quinone, steroid, saponin, monoterpene, and sesquiterpene [8]. Kusdarwati's study on the antibacterial effect of the adas fruit extract (Foeniculum vulgare) on Micrococcus luteus bacteria found that the flavonoid compounds saponin and tannin are antibacterial phenolic compounds that have the same chemical structure within plants. The compound exerts its antibacterial mechanism by denaturing the bacterial wall protein so that bacterial metabolism is inhibited, resulting in low bacterial growth [11]. This study differed from the previous study in the use of breadfruit leaf and adas fruit extract. Trijani's study found that if the antibacterial concentration was low, phenol compounds would easily decompose and lead to leakage of bacterial walls. At high concentrations, phenol compounds cause bacterial cell membranes lysis [12].

At the maturation phase, breadfruit leaf extract at a concentration of $5 \%$ increased $S$. mutans viability (Fig. 2). Based on the research conducted by Sabir, in the maturation phase, antibacterial compounds at low concentrations would effectively inhibit the growth of $S$. mutans when applied continuously [13]. If they are not applied continuously, it is recommended to use high concentrations [13].

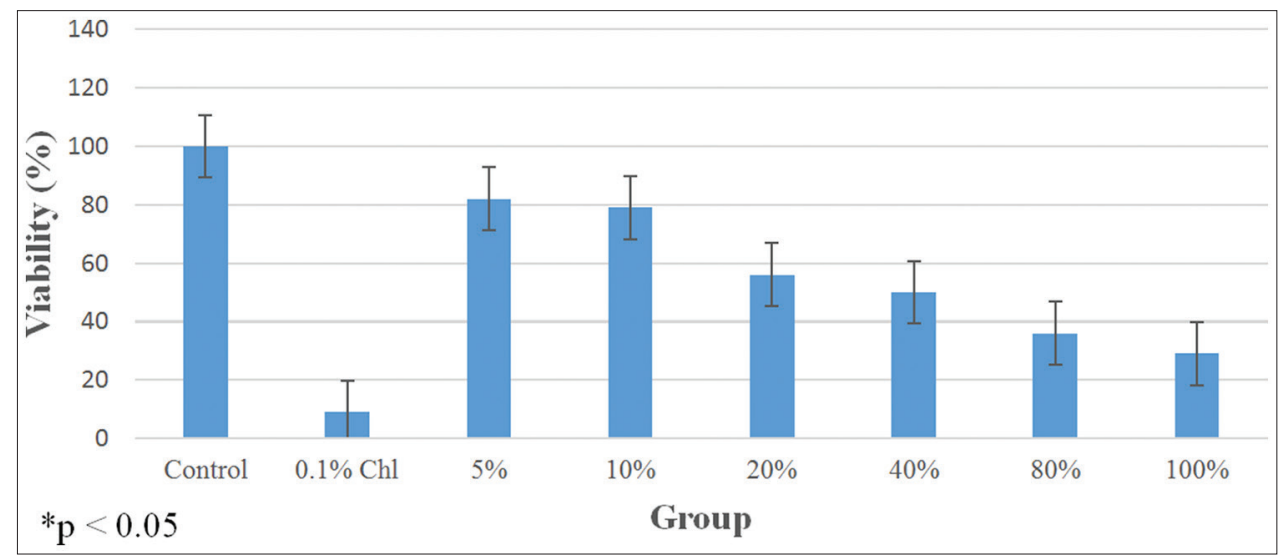

Fig. 1: Streptococcus mutans biofilm viability during the accumulation phase (20 $\mathrm{h})$ after exposure to breadfruit leaf extract 


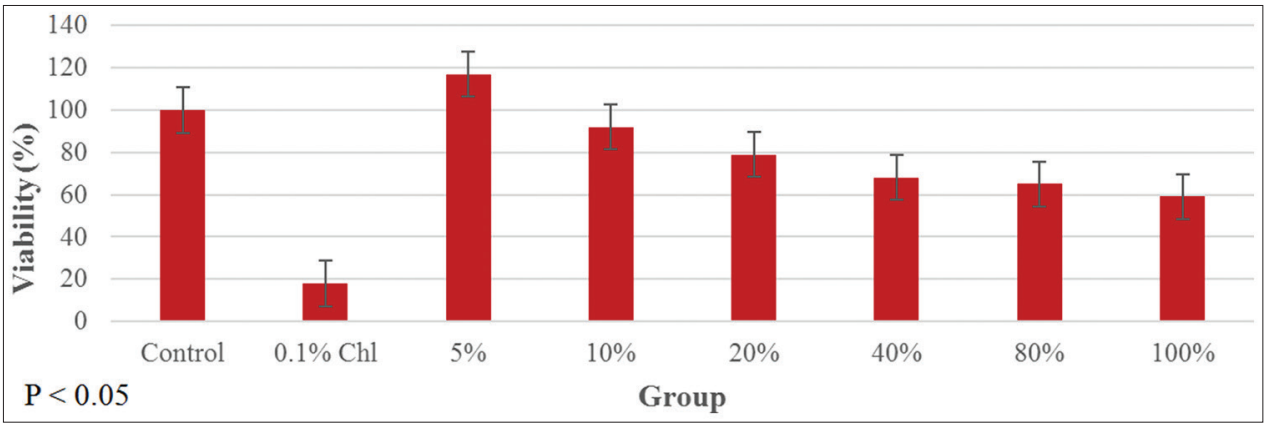

Fig. 2: Streptococcus mutans biofilm viability during maturation phase $(24 \mathrm{~h})$ after exposure to breadfruit leaf extract

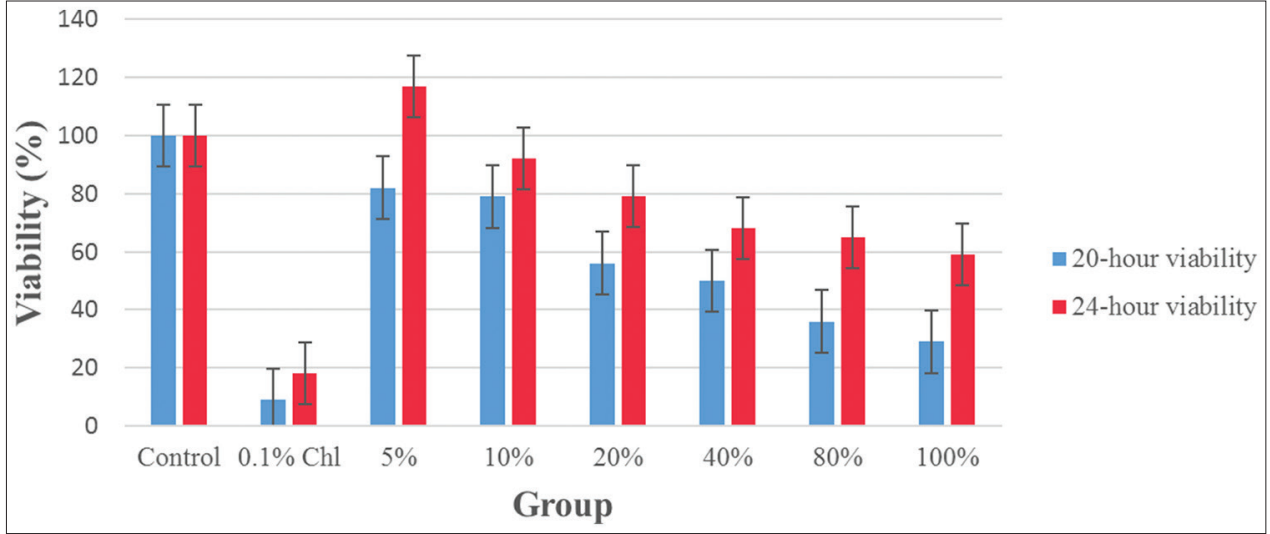

Fig. 3: Streptococcus mutans biofilm viability $20 \mathrm{~h}$ (accumulation phase) and $24 \mathrm{~h}$ (maturation phase) after exposure to breadfruit leaf extract

This result may be influenced by the extracellular matrix of bacteria found on biofilms so it will limit the penetration of antibacterial agents. The thicker the biofilm, the more slowly the antibacterial compound diffuses into the biofilm, thus causing the occurrence of antibacterial resistance at the maturation phase [14]. We found that in the maturation phase, the breadfruit leaf extract was not capable of reducing $S$. mutans viability. Factors that may affect the antibacterial activity are environmental $\mathrm{pH}$, seed components, active substance stability, and bacterial metabolic activity [15].

In the maturation phase, there can be a reduction in the bacterial activity during the process of biofilm formation due to nutritional deficiency [5]. Based on the research conducted by Hidayaningtias, viability would increase in the maturation phase if bacteria were given a medium for growth [16]. In this study, the breadfruit leaf extract was mixed with BHI broth. At 5\% breadfruit leaf extract concentration, the amount of BHI broth was higher than the amount of breadfruit leaf extract; therefore, the antibacterial compound could not work optimally. As a result, the biofilm viability increased.

The positive control used in this study was $0.1 \%$ chlorhexidine, which prevents caries by inhibiting plaque formation[15]. Rachmawati stated that the antibacterial effect of temulawak ethanol extract on S. mutans biofilm was equivalent to that of chlorhexidine[16]. In this study, S. mutans viability when exposed to breadfruit leaf extract was higher than that with $0.1 \%$ chlorhexidine.

The results of the MTT test with breadfruit leaf extract exposure at various concentrations demonstrated that $S$. mutans viability in the accumulation phase was lower than that in the maturation phase (Fig. 3). Based on the research conducted by Hojo, antibacterial compounds effectively inhibit the growth of bacteria in the accumulation phase [10]. In the accumulation phase, the microorganisms have a solid matrix structure, which is primarily composed of polysaccharide. According to the study conducted by Rachmawati et al., the Gram-positive cell wall structure is more simple and single layered with a low lipid content of $1 \%-4 \%$ that allows bioactive materials into cells [17].

\section{CONCLUSION}

In the accumulation phase, breadfruit leaf extract at concentrations of $5 \%, 10 \%, 20 \%, 40 \%, 80 \%$, and $100 \%$ can reduce S. mutans biofilm viability. In the maturation phase, breadfruit leaf extract at concentrations of $10 \%, 20 \%, 40 \%, 80 \%$, and $100 \%$ can reduce $S$. mutans biofilm viability. S. mutans biofilm viability in the accumulation phase was lower than that in the maturation phase for all exposure groups. $S$. mutans viability at $5 \%$ breadfruit leaf extract concentration increased in the maturation phase.

\section{CONFLICTS OF INTEREST}

There are no conflicts of interest to declare.

\section{REFERENCES}

1. Katno, Pramono S. The Benefits and Safety of Medicinal Plants and Traditional Medicines. Yogyakarta: Balai Penelitian Tanaman Obat Tawangmangu, Fakultas Farmasi UGM; 2005. p. 8-9.

2. Mataharinews. Cancer Treatment with Breadfruit Leaves. Available from: http://www.mataharinews.com/kesehatan/obat-penyakit/1743mengobati-kanker-dengan-daun-sukun.html.

3. Litbang Deptan Sukun. National Workshop on Breadfruit Development. Available from: http://www.pustaka.litbang.deptan.go.id/publikasi/ wr11093.pdf.

4. Mount G, Hume WR. Dental Caries. Preservation and Restoration of Tooth Structure. $2^{\text {nd }}$ ed. Queensland: Knowledge Books and Software; 2005. p. 21-5.

5. Wen ZT, Yates D, Ahn SJ, Burne RA. Biofilm formation and virulence expression by Streptococcus mutans are altered when grown in dualspecies model. BMC Microbiol 2010;10:111.

6. Michalek SM, McGhee JR. Virulence of Streptococcus mutans: An antibiotic-suppressed rat model for studies of pathogenesis. J Dent Res 1977;56:205-11. 
7. Prescott LM, Harley JP, Klein DA. Microbiology. $5^{\text {th }}$ ed. Boston: McGraw-Hill; 2002. p. 602-21.

8. Abdassah M, Sumiwi SA, Hendrayana J. Breadfruit leaf extract formulation with gel base as anti-inflammatory. J Farm Indones 2009;4:199-209.

9. Pankey GA, Sabath LD. Clinical relevance of bacteriostatic versus bactericidal mechanisms of action in the treatment of gram-positive bacterial infections. Clin Infect Dis 2004;38:864-70.

10. Purnamasari DA, Munadziroh E, Yogiartono RM. The concentration of cocoa bean extract as a natural material in inhibiting the growth of Streptococcus mutans. J PDGI 2010;59:1-18.

11. Kusdarwati R, Sari L, Mukti AT. Antibacterial power of fennel fruit extract (Foeniculum vulgare) against Microccus luteus bacteria in vitro. J Ilmiah 2010;2:35-31.

12. Suwandi T. Development of the Antibacterial Potential of Hibiscus sabdariffa L. (Rosela) Towards Streptococcus Inducing Gingivitis towards Standard Herbal Medicine [Dissertation]. Jakarta: Universitas Indonesia; 2012

13. Sabir A. Antibacterial activity of Trigona Sp towards Streptococcus mutans (in vitro). Maj Ked Gigi 2005;38:135-41.

14. Mah TF, O'Toole GA. Mechanisms of biofilm resistance to antimicrobial agents. Trends Microbiol 2001;9:34-9.

15. Jawettz E, Melnick JL, Adelberg EA. Medical Microbiology. $9^{\text {th }}$ ed. USA: Lange Medical Book; 1991. p. 149-52.

16. Hidayaningtias P. Comparison of the Antibacterial Effect of Steeping Betel Leaf (Piper betle Linn) towards Streptococcus mutans at Different Contact Times and Concentrations [Dissertation]. Semarang: Universitas Diponegoro; 2008.

17. Rachmawati F, Nuria MC, Sumantri. Antibacterial Activity Test for Chloroform Fraction of (Centella asiatica (L) Urb) Ethanol Extract and Indentification of its Active Compounds. [Dissertation]. Yogyakarta: Universitas Gadjah Mada; 2011. 